\title{
Examining the Symbolic Landscapes in the Context of Sustainable Culture
}

\author{
Tuğba DÜZENLi1*, Elif Merve ALPAK², Abdullah çiĞDEM ${ }^{3}$ \\ ORCID 1: 0000-0001-6957-3921 \\ ORCID 2: $0000-0002-2306-4299$ \\ ORCID 3: $0000-0002-6468-3600$ \\ Department of Landscape Architecture, Faculty of Forestry, Karadeniz Technical University, 61080, Trabzon- \\ Turkey. \\ *e-mail: tugbaduzenli@gmail.com.
}

\begin{abstract}
A society with a culture of sustainability perceives urban culture more intensely, and a culture of sustainability could also develop more easily in societies that strongly perceive the urban culture. On sustainability of urban spaces, the relationship between physical, sociocultural and psychological sub-components is effective. Therefore, environmental organizations that allow cultural sustainability are very important in preventing the alienation of the members of the society to each other and the space and creating cultural diversity. Contemporary cities and spaces are defined and characterized by symbolic references. The present study focused on the concepts of cultural sustainability and symbolic landscape. The primary aim of the present study was to investigate the physical (activity and space) interaction of cultural change in symbolic landscapes and satisfaction with the spaces.
\end{abstract}

Initially, a survey was conducted with 18 experts to determine the effects of landmarks on urban cultural sustainability and then, the same survey was conducted with 186 occupants in Trabzon province open spaces in Turkey. In the survey, the sustainability of open spaces that symbolize the city was questioned. Then, One-Sample $T$ test and Correlation analyzes were conducted on the survey data using SPSS (v. 23.0) software.

It was determined that Hagia Sophia and Boztepe were the most influential landmarks on urban cultural sustainability. As a result, it was demonstrated that Hagia Sophia, Boztepe, Meydan park, Ganita, City Walls, Atatürk mansion, Soumela Monastery, and Uzungol were effective on cultural sustainability as urban landmarks. One-Sample T test was conducted with SPSS (v. 23.0) software to determine whether the differences in the effects of the landmarks on cultural sustainability based on activity diversity were statistically significant. The test results demonstrated that the landmarks had statistically different effects on cultural sustainability based on reflecting the activity diversity $(p<0.01)$.

The present study findings demonstrated that Meydan park and Ganita stood out as the urban landmarks that affected cultural sustainability the most in satisfaction. Because, these two spaces are easy to reach in the urban center with historical significance and dense occupancy. Thus, they were prominent in cultural sustainability.

Keywords: Sustainability, culture, symbolic landscape, urban space.

Atıf: Düzenli, T., Alpak, E.M., Çiğdem, A. (2019). Examining the Symbolic Landscapes in the Context of Sustainable Culture. Mimarlık Bilimleri ve Uygulamaları Dergisi (MBUD), 4 (2), 97-104.

DOI: $\underline{10.30785 / \mathrm{mbud} .553779}$ 


\section{Kültürel Sürdürülebilirlik Bağlamında Sembolik Peyzajların Incelenmesi}

\section{Öz}

Sürdürülebilirlik kültürü oluşmuş bir toplum, kent kültürünü daha yoğun bir şekilde algılar, kuvvetli bir şekilde kent kültürünü hisseden toplumlarda sürdürülebilirlik kültürü de daha kolay oluşabilir. Kentsel mekânların sürdürülebilirliğinde; fiziksel, sosyokültürel ve psikolojik alt bileşenleri arasındaki ilişki etkilidir. Bu nedenle kültürel sürdürülebilirliği sağlayan çevre düzenlemeleri, toplumun birbirine ve mekâna yabancılaşmasına engel olması ve kültür çeşitliliği oluşturması açısından oldukça önemlidir. Günümüz kentleri ve mekânları simgesel referanslarla karakterize edilerek tanımlanır. Bu araştırmada kültürel sürdürülebilirlik ve simgesel peyzaj kavramlarına odaklanılmıştır. Simgesel peyzajlardaki kültürel değişimin fiziksel (etkinlik ve mekân) etkileşiminin ve mekânlara yönelik memnuniyetin sorgulanması bu çalışmanın öncelikli amacı olmuştur.

Çalışma kapsamında simgesel peyzajların kentin kültürel sürdürülebilirliğine etkilerini belirlemek amacıyla önce 18 uzmanla daha sonra Türkiye'nin Trabzon kenti açık mekânlarında 186 kullanıcıyla anket yapılmıştır. Ankette kenti simgeleyen açık mekânların sürdürülebilirliği sorgulanmıştır. Daha sonra anket sonuçlarına SPSS (v. 23.0) kullanılarak One-Sample T testi ve Korelasyon analizleri uygulanmıştır.

Ayasofya ve Boztepe' nin etkinlik açısından kentin kültürel sürdürülebilirliğinde en etkili simgesel mekânlar olduğu belirlenmiştir. Sonuçta, Ayasofya, Boztepe, Meydan parkı, Ganita, Surlar, Atatürk köşkü, Sümela Manastırı, Uzungöl kentin simgesel mekânları olarak kültürel sürdürülebilirlikte etkili oldukları ortaya konmuştur. Simgesel mekanların etkinlik çeşitliliği açısından kültürel sürdürebilirliğe etkilerindeki farklılıkların istatistiksel olarak anlamlı olup olmadığını belirlemek için SPSS (v. 23.0) kullanılarak One-Sample T testi yapılmıştır. Testin sonuçları simgesel mekânların; etkinlik çeşitliliğini yansıtma açısından kültürel sürdürülebilirliği istatiksel olarak farklı etkilediğini göstermiştir $(p<0.01)$

Çalışma sonucunda; Meydan parkı ve Ganita da kentin merkezi iki simgesel mekânı olarak memnuniyette kültürel sürdürülebilirliği en etkileyen yerler olarak öne çıkmıştır. Çünkü iki mekân da kentin kolay erişebilir noktalarında ve tarihi geçmişe sahip, yoğun kullanımlı yerlerdir. Bu nedenle kültürel sürdürülebilirlikte de ön plana çıkmıştırlar.

Anahtar Kelimeler: Sürdürülebilirlik, kültür, sembolik peyzaj, kent mekânı.

\section{Aim and Background}

While sustainability is defined as "ensuring the long-term existence of the socially-formed relationships between the society and nature" (UNESCO-MOST, 1996) sustainable development was defined as the development that provides sustainability. In other words, as the ultimate point that development could meet has been identified as the most recent point of development. The ecological, sociocultural and economic sustainable development components, which are in continuous interaction, complement and define each other (Blowers, 1997; Reboratti, 1999). The common objective of such components is to improve the quality of life (Sachs, 1997; Çahantimur and Yıldız, 2008).

The objective to improve the quality of life in cities necessitated to address all systems, which make an urban environment livable, within the context of quality of life. Consequently, the discussions on the means to realize sustainable urban development were initiated and the related studies increased. Eventually, sustainable urban development was determined as the approach that "develops quality of life in cities and preserves their existing natural capacities while developing physically and realizes economic developments without disrupting the social balance between the economy and ecosystem and without eliminating the opportunity of future generations in meeting their needs" (Nijkamp and Perrels, 1994; Haughton and Hunter, 1994).

Rapoport (2004) stated that the mechanisms between man and his environment were cultural, they were related to culture and they changed with culture. Correspondingly, it is essential to determine the rate of change experienced in the process of urbanization, the activities that emerged and disappeared due to such rate of change and the spatial characteristics that enable these activities (Bayramoğlu et al., 2016). Furthermore, research efforts (Gür, 1996) demonstrated that it was significant to determine the process of change and the change in behavior (use culture / activity) as well as the definition of cultural elements in the design of new environments and alternative solutions, 
and, in parallel, indicated that the data collection from both traditional environments and environments going through transformation and the analysis of such environmental data was significant (Gür, 1996). Hence, it could be concluded that the transformation process in cultural elements result with various activities that were transformed, and such change becomes one of the most important factors in the availability, sustainability and success of the spaces. The present research focuses on the symbolic landscapes, which have or lost cultural sustainability due to newly introduced activities, i.e., the diversity of activities, in the city of Trabzon. Furthermore, the present study primarily aimed to investigate the level of satisfaction regarding the physical interaction (activity and space) and spaces due to cultural change in the symbolic landscapes.

Adam (2012) emphasized the responsibility of environmental designers in terms of their ability to create and transform symbols that contribute the identity and culture of individuals and communities. Lang (1994) also highlighted that the designers were responsible for the acknowledgement of symbols related to the identity of a group and for the means to transform or use these symbols for the continuity in providing support. Padua (2007) criticizes the post-traditional landscape of several contemporary cities since they were characterized through symbolic references that break the connection between the local history and the society. Therefore, the present study focused on the symbolic landscapes in the city of Trabzon as the study areas.

\section{Experimental Design}

Trabzon is the oldest and largest port city in the Black Sea region and was founded at the outset of the Asian and Middle Eastern transit route (Zorlu et al., 2010). Trabzon constitutes the urban identity and culture through its natural, architectural, cultural and various symbolic features (Figure 1). The city has a rich culture due to its traditions-customs, climate, nature, lifestyles of individuals and its architecture.

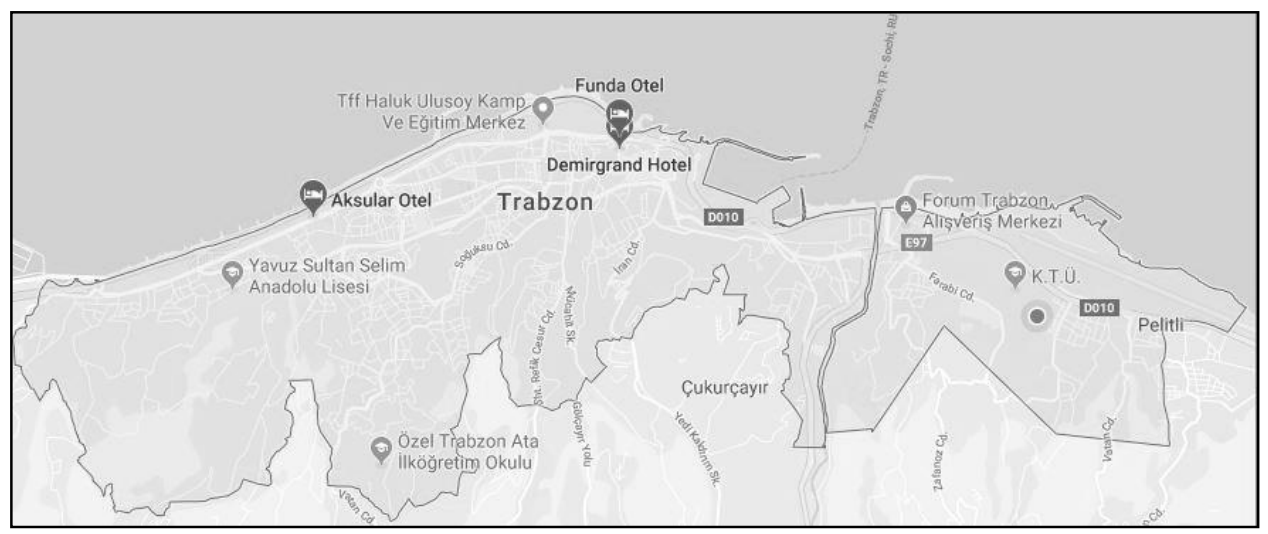

Figure 1. Study Area

\subsection{The survey and the questionnaire}

The data collection was completed in two phases. The first phase included a survey, which was intended to determine the symbolic spaces in the city, through the opinions of 18 experts.

In the second phase, 186 city inhabitants were submitted a questionnaire, which was formed due to the expert opinions on symbolic spaces of the city (Hagia Sophia, Boztepe, Meydan Park, Ganita, City Walls, Ataturk Mansion, Sümela Monastery and Uzungöl) and was intended to determine user preferences towards these spaces. The questionnaire was structured with the list of symbolic spaces and a 5-point scale (1: strongly low, 2: low, 3: average, 4: high, 5: strongly high), which was used to measure the degree of symbolic spaces in reflecting cultural sustainability (current activity diversity, the level of preservation for old activities and satisfaction level based on the physical change).

\section{Results and Discussion}

The demographics of the participants of both the survey and the questionnaire were presented in Table 1. 
Table 1. Demographics of the questionnaire participants

\begin{tabular}{|c|c|c|c|}
\hline & Demographics & & Sum \\
\hline \multirow{8}{*}{ 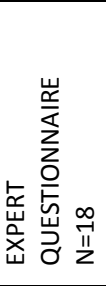 } & \multirow[t]{2}{*}{ Gender } & Male & 7 \\
\hline & & Female & 11 \\
\hline & \multirow[t]{3}{*}{ Age } & $30-39$ & 5 \\
\hline & & $40-49$ & 6 \\
\hline & & 50 and more & 7 \\
\hline & \multirow[t]{3}{*}{ Occupation } & Landscape Architect & 12 \\
\hline & & Architect & 3 \\
\hline & & Urban Planner & 3 \\
\hline \multirow{10}{*}{ 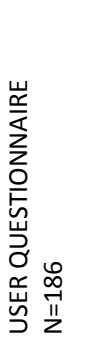 } & \multirow[t]{2}{*}{ Gender } & Male & 98 \\
\hline & & Female & 88 \\
\hline & \multirow[t]{4}{*}{ Age } & $18-29$ & 13 \\
\hline & & $30-39$ & 61 \\
\hline & & $40-49$ & 57 \\
\hline & & 50 and more & 55 \\
\hline & \multirow[t]{4}{*}{ User Type } & Self-Employed & 78 \\
\hline & & Housewife & 43 \\
\hline & & Civil Servant & 87 \\
\hline & & Student & 28 \\
\hline
\end{tabular}

\subsection{Findings of the expert survey}

In order to determine the symbolic spaces and spatial elements in the city of Trabzon, a survey was conducted with 18 participants, who were landscape architects, architects and urban planners. The experts were asked to list the symbolic spaces and their elements for the city of Trabzon. The outcomes of the survey were listed in Table 2 . The symbolic spaces of the city were classified, and their images were presented in Figure 2.

Table 2. Symbolic spaces and elements determined via expert opinion

\begin{tabular}{lc}
\hline Symbolic Spaces & Frequency \\
\hline Hagia Sophia & 14 \\
\hline Boztepe & 13 \\
\hline Meydan Park & 11 \\
\hline Ganita & 10 \\
\hline Atatürk Mansion & 9 \\
\hline City Walls & 9 \\
\hline Sümela Monastery & 8 \\
\hline Uzungöl & 7 \\
\hline
\end{tabular}

Figure 2. Images of the symbolic spaces

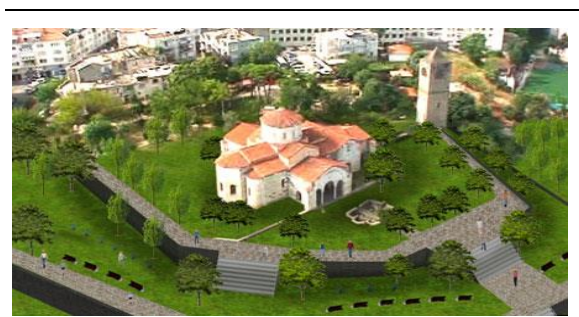

Hagia Sophia

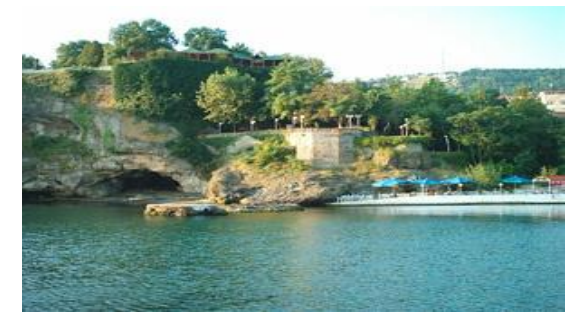

Ganita

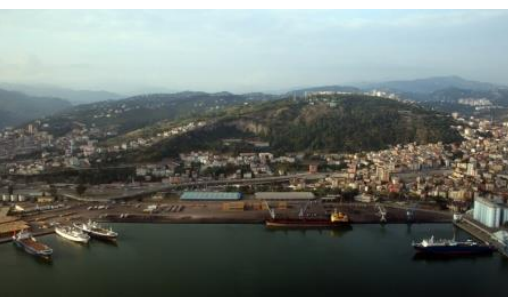

Boztepe

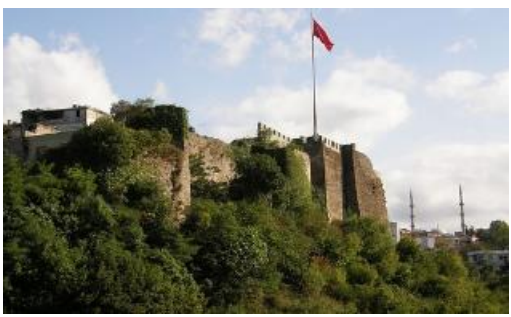

City Walls

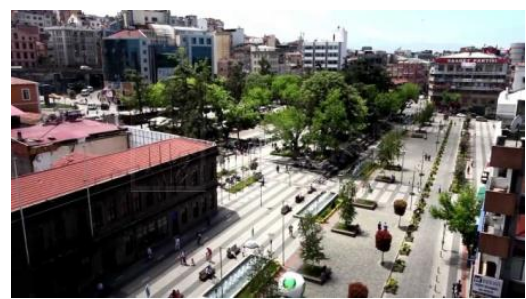

Meydan Park

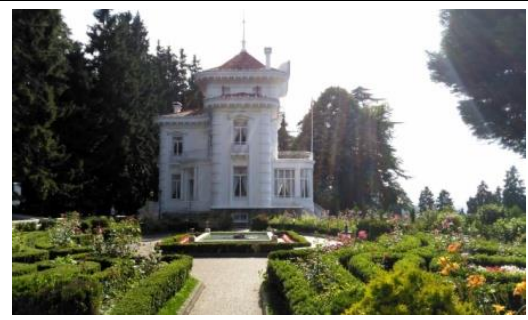

Ataturk Mansion 


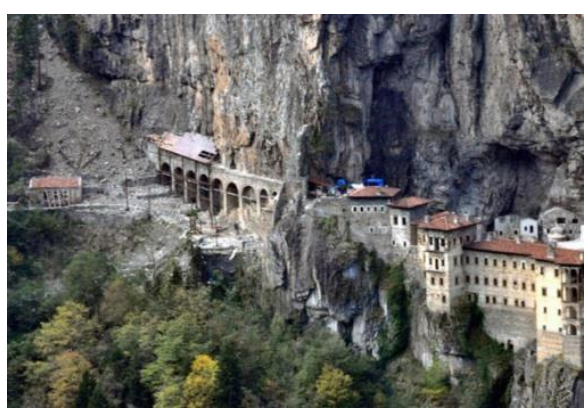

Sumela Monastery

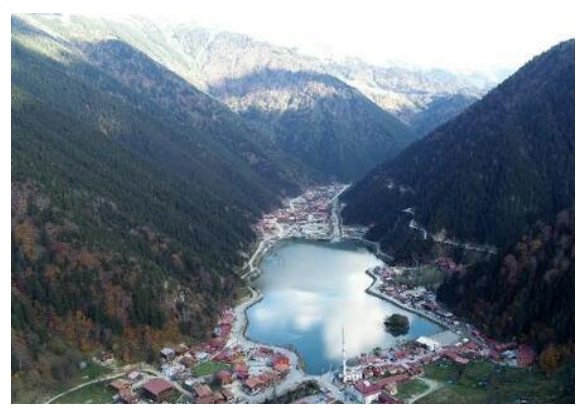

Uzungol

\subsection{Findings on cultural sustainability}

The responses to the question, "How much the space offer activity diversity?", which was asked with the aim to determine the effects of symbolic spaces on cultural sustainability, indicated that "Hagia Sophia" and "Boztepe" received the highest average values of 3,77 and 3,46, respectively. In other words, user opinions established that these two symbolic spaces in the city reflected cultural diversity in the best way through offering the highest diversity of activities. "Meydan Park" and "Ganita" also reflected sustainability as symbolic spaces. The frequency distributions of other spaces were presented in Figure 3. The lowest score was received by the "City Walls".

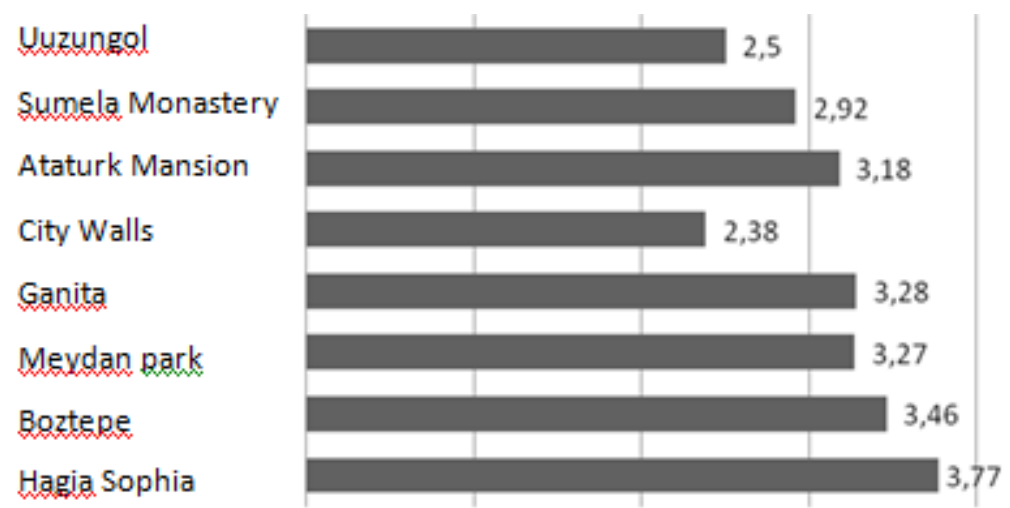

Figure 3. Frequency distributions for the symbolic spaces in reflecting the level of activity diversity

One-Sample T test was performed via SPSS (v. 23.0) software, in order to determine whether there existed statistically significant differences in the effects of activity diversities on cultural sustainability. The results of the test indicated that symbolic spaces, which reflected diversity of activities, affected cultural sustainability with statistically significant difference $(p<0.01)$ (Table 3$)$. Therefore, it was concluded that the diversity of activities offered via symbolic spaces was an important factor for cultural sustainability.

Table 3. Evaluation of the effects of symbolic spaces on cultural sustainability based on diversity of activities

\begin{tabular}{|c|c|c|c|c|c|c|}
\hline & \multirow[b]{2}{*}{$\mathrm{t}$} & \multirow[b]{2}{*}{$\mathrm{df}$} & \multirow[b]{2}{*}{ Sig. (2-tailed) } & \multirow[b]{2}{*}{ Mean Difference } & \multicolumn{2}{|c|}{ 95\% Confidence Interval of the Difference } \\
\hline & & & & & Lower & Upper \\
\hline Hagia Sophia & 46,934 & 185 & ,000 & 3,774 & 3,62 & 3,93 \\
\hline Boztepe & 46,750 & 185 & 000 & 3,457 & 3,31 & 3,60 \\
\hline Meydan Park & 45,378 & 185 &, 000 & 3,269 & 3,13 & 3,41 \\
\hline Ganita & 43,738 & 185 &, 000 & 3,280 & 3,13 & 3,43 \\
\hline City Walls & 31,728 & 185 &, 000 & 2,382 & 2,23 & 2,53 \\
\hline Ataturk Mansion & 46,418 & 185 & ,000 & 3,183 & 3,05 & 3,32 \\
\hline Sumela Monastery & 45,063 & 185 &, 000 & 2,925 & 2,80 & 3,05 \\
\hline Uzungol & 44,937 & 185 &, 000 & 2,500 & 2,39 & 2,61 \\
\hline
\end{tabular}

The responses to the question, "How much the space preserves activities of old times?", which was asked with the aim to determine the effects of symbolic spaces on cultural sustainability, indicated 
that "Hagia Sophia", "Boztepe" and "Ganita" received the highest average values of 3,92, 3,58 and 3,31 , respectively. In other words, users suggested that these three symbolic spaces in the city reflected cultural sustainability through preserving the activities of old times. The symbolic spaces of "Meydan Park" and "Atatürk Mansion" also reflected sustainability at a good level. The frequency distributions related to other spaces were presented in Figure 4. The lowest value was received by the "City Walls".

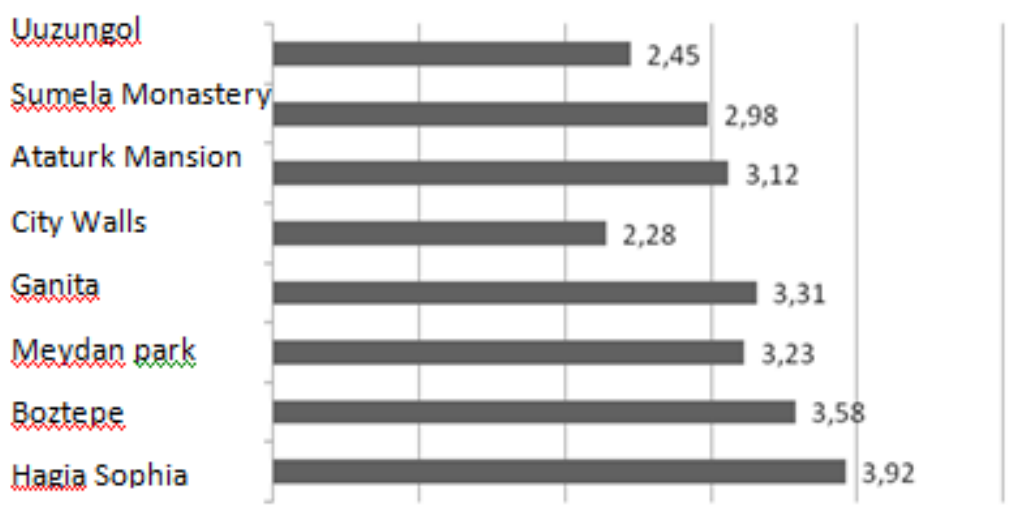

Figure 4. Frequency distributions of symbolic spaces for preserving activities of old times

One-Sample T test was performed via SPSS (v. 23.0) software, in order to determine whether there existed statistically significant differences in the effects of preserving old activities on cultural sustainability. The outcomes of the analysis indicated that preserving activities of old times provided a statistically significant difference on cultural sustainability $(p<0.01)$ (Table 4$)$. Therefore, it was possible to assert that the level of preserving activities of old times in symbolic spaces was a highly significant factor for cultural sustainability.

Table 4. Evaluation of the effects of symbolic spaces on cultural sustainability based on preserving activities of old times

\begin{tabular}{|c|c|c|c|c|c|c|}
\hline & \multirow[b]{2}{*}{$\mathrm{t}$} & \multirow[b]{2}{*}{ df } & \multirow[b]{2}{*}{ Sig. (2-tailed) } & \multirow[b]{2}{*}{ Mean Difference } & \multicolumn{2}{|c|}{$95 \%$ Confidence Interval of the Difference } \\
\hline & & & & & Lower & Upper \\
\hline Hagia Sophia & 48,327 & 185 & ,000 & 3,925 & 3,62 & 3,93 \\
\hline Boztepe & 46,727 & 185 & ,000 & 3,575 & 3,31 & 3,60 \\
\hline Meydan Park & 44,544 & 185 & , 000 & 3,231 & 3,13 & 3,41 \\
\hline Ganita & 45,549 & 185 & ,000 & 3,312 & 3,13 & 3,43 \\
\hline City Walls & 30,884 & 185 & ,000 & 2,280 & 2,23 & 2,53 \\
\hline Ataturk Mansion & 50,850 & 185 &, 000 & 3,118 & 3,05 & 3,32 \\
\hline $\begin{array}{l}\text { Sumela } \\
\text { Monastery }\end{array}$ & 44,181 & 185 & ,000 & 2,984 & 2,80 & 3,05 \\
\hline Uzungol & 49,601 & 185 & ,000 & 2,452 & 2,39 & 2,61 \\
\hline
\end{tabular}

A correlation analysis was performed to determine the relationship between symbolic spaces and cultural sustainability (Table 5). Based on the results of the correlation analysis, "Meydan Park" was determined to be the space, which was most associated with sustainability, and was followed by "Ganita". It was determined that all spaces were influential on the urban identity. At a central location, Meydan Park has a square form surrounded by main streets on four sides, it includes cedar trees, a tea garden in the south, and the municipality is located to the east of the park. "Ganita" tea garden, which is frequently used, is the only piece of nature existing at the coastal line of the city and has a history of approximately 120 years. Therefore, it was observed that these spaces also stood out in terms of cultural sustainability.

Table 5. Symbolic spaces that are related to urban identity

\begin{tabular}{|c|c|c|c|c|c|c|c|c|c|c|}
\hline & & & 1 & 2 & 3 & 4 & 5 & 6 & 7 & 8 \\
\hline \multirow{5}{*}{ 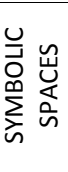 } & (1) & Hagia Sophia & - & $905^{* *}$ & $884^{* *}$ & $886^{* *}$ & $698^{* *}$ & $889^{* *}$ &, $773^{* *}$ & $442^{* *}$ \\
\hline & (2) & Boztepe & & - & $923^{* *}$ & ,929** & $694^{* *}$ & $897^{* *}$ &, $747^{* *}$ &, $540^{* *}$ \\
\hline & (3) & Meydan Park & & & - & $947^{* *}$ &, $714^{* *}$ & $958^{* *}$ & $850^{* *}$ & $609^{* *}$ \\
\hline & (4) & Ganita & & & & - &, $718^{* *}$ & $935^{* *}$ & $800^{* *}$ & $529^{* *}$ \\
\hline & (5) & City Walls & & & & & - &, $734^{* *}$ &, $712^{* *}$ & $491^{* *}$ \\
\hline
\end{tabular}




\begin{tabular}{|c|c|c|c|c|c|c|c|c|c|}
\hline (6) & Ataturk Mansion & & & & & & - & $866^{* *}$ &, $602^{* *}$ \\
\hline (7) & Sumela Monastery & & & & & & & - &, $555^{* *}$ \\
\hline (8) & Uzungol & & & & & & & & - \\
\hline \multicolumn{2}{|c|}{$\begin{array}{l}\text { Satisfaction with the symbolic } \\
\text { spaces }\end{array}$} & ,798** & ,829** & $894^{* *}$ & $853^{* *}$ &, $667^{* *}$ & $853^{* *}$ &, $744^{* *}$ &, $595^{* *}$ \\
\hline
\end{tabular}

\section{Conclusions}

The concept of culture, which is considered as an open system in interaction with other close or distant communities (Emery, 1972), is approached as a whole with the physical environment and is accepted once sustained as the reflection of a space (Lang, 1987). The need of individuals to attach meaning to their physical environment (Carr et al., 1992; Doğan, 2016; Regular et al., 2017; Kurt et al., 2016) is ensured through sustainability and such condition contributes to the sense of belonging and satisfaction of individuals towards a space (Düzenli et al., 2017; Düzenli et al., 2019). The present study was planned to examine the activities, the spatial characteristics that enable these activities and the preservation of old activities in order to tangibly evaluate the reflection of the sustainable culture on the symbolic space. In the present study, the cultural continuity of Trabzon's symbolic spaces in the historical process was questioned within the context of physical change. The most important aspect of the research resides in its approach to define cultural change through physical (activity and space) definition within the context of sustainability. The physical change and satisfaction level of symbolic spaces within this approach was influential in defining the cultural change.

Once the changes in diversity results of the physical change data were examined, it was observed that, during the historical process from past to present, there were certain changes in activities, although similar activities were carried out in symbolic spaces. The outcome that Boztepe and Hagia Sophia were the most effective spaces in terms of the cultural sustainability of the city, the diversity of existing activities and the preservation of old activities could be associated with their differences (uniqueness) in their environment. Hagia Sophia presents uniqueness with its historical structure and Boztepe, with its green texture, when compared to other spaces in their surroundings, and these spaces stand out with their differences. Such condition renders both places more memorable and perceptible, and they affect sustainability through the activities and frequency of use that lasted from past to present. Furthermore, both landmarks provide a high level of reference point for the users. These spaces stood out as two symbolic spaces which could be expressed as the identifiers of the city. The reason behind the lowest ranking of Uzungöl was possibly due to the deterioration of its natural structure and the decrease of its symbolic characteristic in recent years, hence its cultural sustainability was adversely affected.

The two other symbolic spaces of the city, Meydan Park and Ganita, also stood out as the two spaces that affected cultural sustainability through the satisfaction levels. This is due to their easily accessible locations in the city and their historical background and frequent use. Therefore, they were also prominent in terms of cultural sustainability. All above-mentioned symbolic spaces have cultural sustainability, since they provide various activities for the users and reflect the activities of old times up to a certain level.

\section{References}

Adam, R. (2012). Identity and Identification: The Role of Architectural Identity in a Globalized World. In H. Casakin, F. Bernardo, (Eds.). The Role of Place Identity in the Perception, Understanding, and Design of Built Environments, pp. 176-193. Bentham Science Publishers.

Bayramoğlu, E., Cindik Akinci, Y. Demirel, Ö. (2016). Interactıon between Urban Desıgn And Ergonomıcs Of Fittıngs: Case Study Of Trabzon Coastal Area, Journal of Environmental Protection and Ecology, 17, 711718.

Blowers, A. (1997). Environmental planning for sustainable development in Blowers, A. ve Evans, B., (eds.), Town Planning Into The 21st Century, Routledge, 33-54, London.

Çahantimur, A., Yıldız, H.T. (2008). Sürdürülebilir kentsel gelişmeye sosyokültürel bir yaklaşım: Bursa örneği. iTÜ Dergisi/A Mimarlık, Planlama, Tasarım. 7(2) :3-13. 
Carr, S., Francis, M., Rivlin, L.G., Stone, A.M. (1992). Public Space, Cambridge University Press, New York, NY, USA.

Doğan, F. (2016).Tarihsel Süreç İçerisindeki Kültürel Değişimin Fiziksel ve Algısal Değişim Bağlamında İrdelenmesi: Trabzon Kent Meydanları Örneği. KTÜ Fen Bilimleri Enstitüsü Peyzaj Mimarlığı Anabilim Dalı doktora tezi.

Düzenli T., Alpak, E.M., Doğan F. (2017).Trabzon Kemeraltı Hıstorıc Bazaar In The Context Of Sustaınable Culture, in: Ecology, Plannıng And Desıgn, Koleva, I., Yuksel, U.D., Benaabıdate, L., Eds., St. Kliment Ohridski University Press, Sofia, pp.104-115.

Düzenli T., Mumcu S., Yilmaz S. (2019). The Effects of Symbolıc Landscapes on City Identıty, the Turkish Online Journal of Design Art and Communication- TOJDAC, 9, 438-448.

Emery, F.E. (1972). Systems Thinking. Harmondsworth:Penguin.

Gür, Ş.Ö. (1996).Mekan Örgütlenmesi, Gür Yayıncılık, Trabzon.

Haughton, G., Hunter, C. (1994).Sustainable cities, Regional Policy and Development Series 7, Jessica Kingsley Publications, 15-20, 24-27, 40, London.

Kurt, S.S., Düzgüneş, E., Kurdoğlu B.Ç., Demirel Ö. (2016). Example Study about Meryemana Valley (Trabzon/Turkey) for Determining the Potential Campground in the Scope of Nature Tourism, Journal of Environmental Protection and Ecology, 17(2): 576-583.

Lang, J. (1994).Urban Design: The American Experience. John Wiley \& Sons, Inc. USA.

Nijkamp, P., Perrels, A. (1994). Sustainable cities in Europe, a comparative analysis of urban energyenvironmental policies, Earthscan Publications Ltd., 4-14, London.

Padua, M.G. (2007). Designing an identity: The synthesis of a post-traditional landscape vocabulary in Hong Kong. Landscape Research, 32 (2), 225-240.

Rapoport, A. (2004). Kültür Mimarlık Tasarım, Çeviri:Selçuk Batur, Yapı-Endüstri Merkezi, İstanbul.

Reboratti, C. (1999).Territory, scale and sustainable development, in Becker, E., Jahn, T.,(eds), Sustainability and the Social Sciences, Zed Books, 207-222, London.

Sachs, W. (1997).Sustainable development, in Redclift, M. ve Woodgate, G. (eds.), The International Handbook of Environmental Sociology, Edward Elgar Publications, 71-80, United Kingdom.

UNESCO-MOST, (1996). Conference report on sustainability as a social science concept, Frankfurt.

Zorlu, T., Aydnnlatan, E., Engin E. (2010). Kentsel Müdahale Kent Kimliği: Tanjant ve Karadeniz Sahil Yollarının Trabzon Kent Kimliğine Etkileri. Mimarlık Dergisi. 352. 